
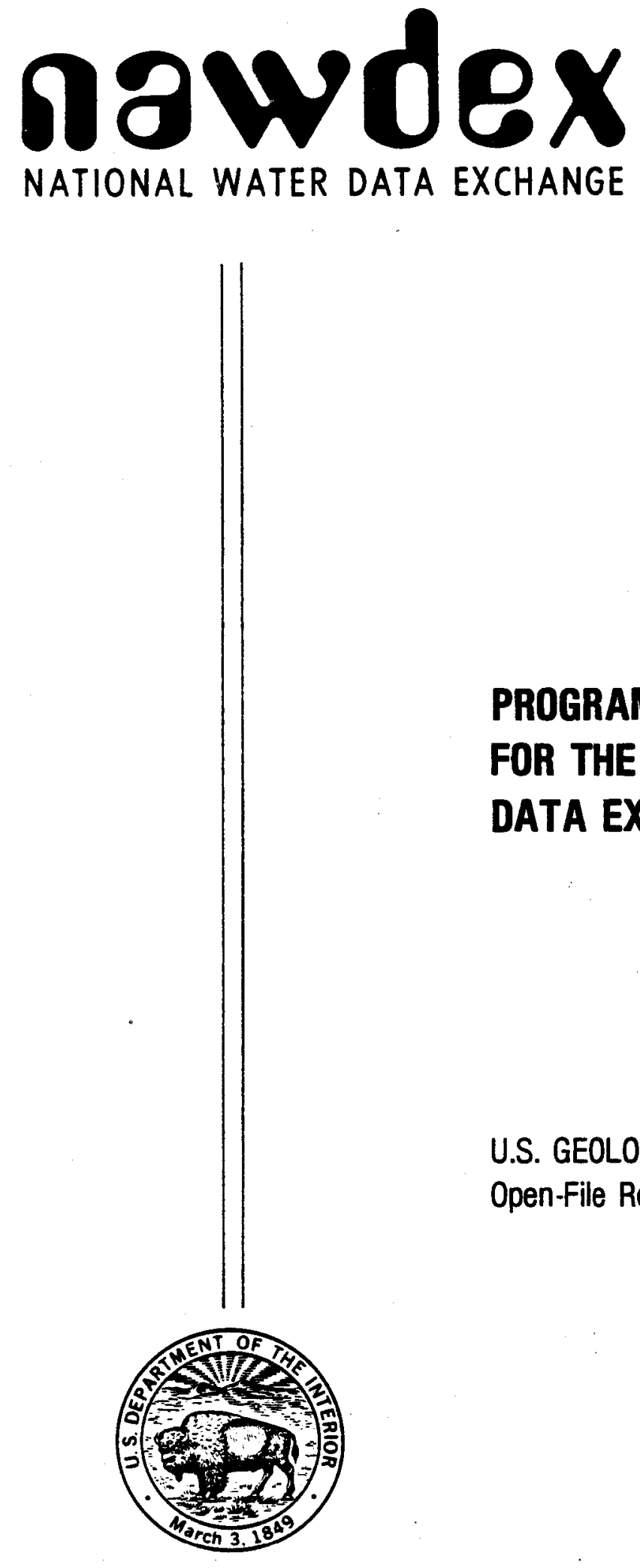

PROGRAM OF OPERATION

FOR THE NATIONAL WATER

DATA EXCHANGE (NAWDEX)

U.S. GEOLOGICAL SURVEY

Open-File Report 85-76 


\section{PROGRAM OF OPERATION FOR THE NATIONAL WATER DATA EXCHANGE (NAWDEX)}

BY MELVIN D. EDWARDS

U.S. GEOLOGICAL SURVEY

Open-File Report 85-76

(Supersedes Open-File Report 77-708)

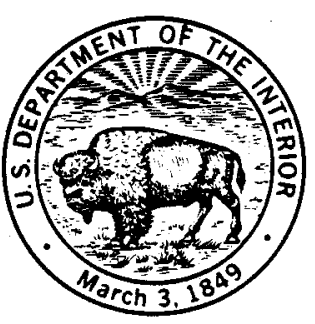




\section{UNITED STATES DEPARTMENT OF THE INTERIOR \\ WILLIAM P. CLARK, Secretary \\ GEOLOGICAL SURVEY \\ Dallas L. Peck, Director}

For additional information write to:

Chief Hydrologist

U.S. Geological Survey

Water Resources Division

421 National Center

Reston, Virginia 22092
Copies of the report can be purchased from:

U.S. Geological Survey Western Distribution Branch Open-File Services Section Box 25425, Federal Center Denver, Colorado 80225 
Page

Abstract . . . . . . . . . . . . . . . . . . 1

Introduction . . . . . . . . . . . . . . . . . . 1

Program Coordination .................... 2

Program Office ................... 2

Designated NAWDEX Representatives . . . . . . . . . 2

Program Management and Administration ............. 3

Program Office .................... 3

Assistance Centers . . . . . . . . . . . . . 3

Program Budgeting .................... 4

Water Data Sources Directory ............. 4

Master Water Data Index . . . . . . . . . . . 4

Member Participation ................... . 5

Committees, Task Forces, Work Groups, and the

Participation of Individuals .............. 6

Summary ....................... 6

References ................... 6 


\author{
Program of Operation \\ for the \\ National Water Data Exchange (NAWDEX)
}

by

Melvin D. Edwards

\title{
ABSTRACT
}

The National Water Data Exchange (NAWDEX) has been established as a nationwide program directed at improving access to water and water-related data and disseminating information about the availability of these data throughout the entire water-resources community. NAWDEX is composed of a confederation of water-oriented organizations working together to facilitate the exchange of data and to improve the technology of data handing and transfer. This program of operation is directed at providing guidelines to assure that all member organizations participate equally and that a climate of cooperation and open communication be established among participating members.

\section{INTRODUCTION}

The National Water Data Exchange (NAWDEX) has been established as a nationwide program directed at improving access to water and water-related data and disseminating information about the availability of these data throughout the entire water-resources community. The need for such a program was recognized in the issuance of U.S. Office of Management and Budget Circular A-67 which established guidelines for "Coordination of Federal Activities in the Acquisition of Certain Water Data." The NAWDEX concept, developed by a subgroup of the (Federal) Interagency Advisory Committee on Water Data, was endorsed by that Committee and its counterpart, the (nonEederal) Advisory Committee on Water Data for Public Use. The coordination charge in Circular A-67 includes both the acquisition of water data from streams, lakes, reservoirs, estuaries, and ground water, and the processing, publication, and storage of these data. By addressing the dissemination of data, NAWDEX complements the functions of the Office of Water Data Coordination (OWDC) in implementing the provisions of the Circular.

The ultimate goal of NAWDEX is to develop a nationwide confederation of organizations working together to facilitate the transfer of data between the collector and user communities, to provide a comprehensive and accurate accounting of existing water and water-related data and where these data may be obtained, and to improve the technology of data handling and transfer.

The success of the NAWDEX program depends upon the support and active participation of its member organizations. Although the NAWDEX Program Office has the responsibility for the overall management and administration of the program, the member organizations are vital agents in the advancement of the program at the national, state, regional, and local levels. The membership 
constitutes a special cadre of talent and expertise that is an invaluable resource to NAWDEX. Its support will assist the NAWDEX program in becoming productive, responsive, and cost effective. It is important that all member organizations participate equally and that a climate of cooperation and open communication be established among the members if the program is to advance effectively.

\section{PROGRAM COORDINATION}

Coordination and communication are keys to the success of the NAWDEX program. Membership support and cooperation are essential to advance the program toward its mission of identifying sources of water data and providing the linkage between those who acquire and those who use water data. Open and effective communication between all members is necessary. A high level of awareness of the needs of the water-data community must also be maintained.

\section{Program Office}

The NAWDEX Program Office, in the U.S. Geological Survey's Water Resources Division, is the central coordinating facility for all NAWDEX activities and is the focal point for establishing channels of communication between member organizations. A NAWDEX Newsletter has been established for this purpose and members are encouraged to contribute to its content. The Newsletter serves as a medium to describe members' data systems, new programs or systems being developed, or services available; to announce new members and new program activities; and to disseminate comments on the NAWDEX program. The Newsletter is not published on a fixed schedule but as needed to announce significant events or advancements within the NAWDEX program. The Program office maintains a mailing list for the free distribution of the Newsletter and members may suggest additions to this mailing list. The Program Office also keeps members informed of NAWDEX activities through the periodic distribution of memoranda, reports, or other documents.

\section{Designated NAWDEX Representatives}

Each member organization is required to designate one or more individuals to serve as NAWDEX representatives. These representatives are the primary contacts for all NAWDEX activities. It is the responsibility of these representatives to keep key staff members in their organizations aware of NAWDEX activities and to advise the Program office and other members of all activities within their organization that are relevant to the NAWDEX program. Updated membership lists identifying all member organizations, designated representatives, and alternates are distributed periodically by the Program Office.

Member organizations often sponsor or participate in topic committees, work groups, and task forces dealing with data acquisition, handling, and dissemination activities which could affect the NAWDEX program. NAWDEX representatives are asked to evaluate such activities in terms of relevance to the NAWDEX mission and its responsibilities and to notify the Program office as appropriate. 


\section{PROGRAM MANAGEMENT AND ADMINISTRATION}

Management and administration of the NAWDEX program is directed at assuring optimum program benefits to all participating members. This requires an effective system of user services for rapid response to requests at a reasonable cost with minimum burden on the responding organization.

\section{Program Office}

The Program office is responsible for the design, development, and implementation of systems and procedures for the operation of the NAWDEX program; the maintenance of a Water Data Sources Directory, a Master Water Data Index, and other program-related data bases; and providing direction to all user-service activities of the program. The Program Office informs all. member organizations of systems development and implementation activities. Members are requested to advise the Program Office of deficiencies and recommend appropriate actions for eliminating them. To assure an opportunity for all members to participate, the following mechanisms are used:

(1) Program objectives for the forthcoming fiscal year are submitted to the membership by the Program Office approximately 90 days before the end of each Federal Fiscal Year (September 30) for review and comment. These objectives include planned systems development or enhancements, new activities, completion schedules for existing projects, and long-range objectives. The membership is asked to review these objectives and recommend changes or additions to the Program Office no later than 45 days prior to the end of the fiscal year. A revised report on program objectives for the forthcoming fiscal year, based upon membership recommendations, is then transmitted to the membership.

(2) Periodic meetings of members' representatives are held at a time and place selected and arranged by the NAWDEX Program Office. The administrative costs and costs of meeting facilities for this meeting are borne by the Program office. Travel and subsistence costs for attendees are borne by each representative's organization. The purpose of this meeting will be to discuss program priorities, to conduct working sessions on matters requiring full membership participation, and to promote personal contact and communication between member representatives.

\section{Assistance Centers}

A national network of Assistance Centers has been established to provide local, convenient access to NAWDEX services and facilities. These Centers are established by mutual agreement between the Program Office and the member organization involved. They are under the direct mangement, administration, and financial support of the member organization. The Program Office provides operational guidelines for the operation of these Centers but has no direct control over their operation. Training relevant to the operation of these Centers is provided by the Program office to the extent allowed by its budgetary constraints. 
Participation by member organizations as Assistance Centers is voluntary . It is desirable to establish Assistance Centers in large population centers and in areas of high user interest. Members having offices in any such areas which are not already serviced by existing Centers are, therefore, requested to consider participating in this activity. Organizations with existing service centers handling data related to the NAWDEX program, such as bibliographic or water-related data services, are also encouraged to participate as Assistance Centers.

\section{Program Budgeting}

Direct Federal funding for NAWDEX is provided by the U.S. Geological Survey through annual Congressional appropriations. Additionally, indirect support is provided through member support in the form of personnel, system support, and other services. There are no plans for the direct transfer of funds from any member organization to the Program office.

Reimbursement for services is an important part of the program budget. While the provision of free services is a worthwhile objective, it is not realistic to expect free responses to all requests, regardless of the degree of complexity. Reimbursement is expected for those services requiring significant financial expenditures or extensive personnel commitments. Charges are made at the discretion of the organization providing the services, and each organization is responsible for collecting its own fees. Fee structures and charging policies should be made known to the Program Office for inclusion in the Water Data Sources Directory.

Water Data Sources Directory

The Water Data Sources Directory (WDSD) is maintained by the Program Office for the purpose of identifying organizations that are sources of water and water-related data, listing the locations within each organization from which these data may be obtained, summarizing the types and amounts of water data available, defining the geographic areas for which an organization has data available, and identifying other sources of an organization's data holdings. Each NAWDEX member is registered in the WDSD. Nonmember organizations are also registered if they are sources of relevant data or services. Each organization is asked periodically to review its registration and to amend information contained in the Directory to accurately reflect its data holdings and level of participation.

The WDSD is used to respond to requests for information about organizations having data available and to refer requestors to sources of data reported in the Master Water Data Index. The WDSD is published periodically, depending upon the frequency of change of its contents.

\section{Master Water Data Index}

The Master Water Data Index (MWDI) is maintained by the Program Office to serve as a mechanism for identifying sites for which water data are available and for providing descriptive information on the available data. NAWDEX members provide information to the Program Office on their data holdings for inclusion in the MWDI. Information on water-data holdings of nonmember organizations is also included if it is voluntarily contributed. Information 
may be provided to the MWDI through manual encoding techniques provided by the Program Office or through computerized interfaces developed cooperatively with the Program Office. Periodically, all contributing organizations are asked to review the information on their data holdings contained in the MWDI and to amend this information, as necessary, to accurately reflect their holdings.

The contents of the MWDI are used to identify data requested by users. Due to the extensive volume of the MWDI Data Base, the Program Office does not publish its contents. However, summaries of the information contained in the MWDI may be published periodically. Retrievals of selected portions of the contents may also be obtained at any time upon request to the Program office or an Assistance Center. Sufficient funds are not available for the unlimited free dissemination of information from the MWDI. Users, members, and contributors, are, therefore, asked to reimburse NAWDEX for large-volume retrievals from the MWDI.

Participation in the MWDI is voluntary and the amount of information entered is at the discretion of the contributing organization. All contributors are encouraged to use the MWDI as a primary inventory and index of their own data holdings, thereby, helping to develop a comprehensive nationwide index of water data.

The cost of development and maintenance of the MWDI is borne by the Program office. Computerized interfaces between member data bases and the MWDI are also supported to the extent possible within the Program Office's budget.

\section{MEMBER PARTICIPATION}

Member organizations of NAWDEX vary in size, function, mission, and program orientation. The level of participation of each member, therefore, varies accordingly. Each member establishes its own level of participation which is generally defined in the terms of the Memorandum of Understanding signed with the Program office. All member organizations are encouraged to be as active as possible in advancing the objectives of the NAWDEX program.

Member are encouraged to:

1. Include NAWDEX services in their long-term planning and budgetary processes.

2. Adopt and implement NAWDEX policies and procedures to the extent practical within their water-data programs.

3. Establish procedures to internally disseminate information on NAWDEX as it becomes available.

4. Utilize the Master Water Data Index as their primary water-data inventory mechanism.

5. Critically review NAWDEX policies and procedures so that the NAWDEX program will accurately represent the entire member organization.

6. Provide feedback to the Program Office on the effectiveness of the NAWDEX program. 
Committees, Task Forces, Work Groups, and the Participation of Individuals

The NAWDEX Program office attempts to manage and administer the NAWDEX program in a manner which will allow each member to participate equally in the operation and advancement of the program. For this reason, each member is considered to serve in an advisory capacity to the Program Office. Due to the anticipated large membership, general-purpose advisory committees are not planned. Instead, small committees or task groups may be established, as needed, for the purpose of advancing specific program missions or elements. Such committees or task groups will be established under the rules and regulations of the Department of the Interior with participants selected from the membership.

Designated representatives of member organizations, or their alternates, may be requested periodically by the Program Office to assist in specific tasks associated with the management and advancement of the NAWDEX program. Subsistence and travel costs for these representatives will be provided by the Program office for these assignments. The designated representatives are asked to inform the Program Office of their availability, or the availability of their alternates, for this type of assistance and to inform the Program office of their general areas of interest and expertise.

\section{SUMMARY}

The program of operation for NAWDEX is directed at providing guidelines to assure that all member organizations participate equally, establishing a climate of cooperation and open communication among participating members, and creating incentives for member organizations to work together through their designated NAWDEX representatives to improve access to water data, and improving the technology of water-data handling and the transfer of data between the collector and user communities. Program operations are periodicaliy reviewed and modified, as needed, to accurately reflect the evolving needs and missions of the program. Every effort is made to maintain NAWDEX as a viable and effective program.

\section{REFERENCES}

U.S. Office of Management and Budget, 1964, Coordination of Federal activities in the acquisition of certain water data: U.S. Office of Management and Budget Circ. A-67, 2 p. 